\title{
Pest Management and Pesticides: A Historical Perspective $^{1}$
}

Frederick M. Fishel ${ }^{2}$

\section{Pests in History}

Civilization has battled pests throughout history. Of the many examples of how pests have impacted human society, one of the most infamous is the Black Plague in Europe in the fourteenth century, when millions of people - approximately one third of Europe's population at that time- - died from a mysterious disease.

The disease was at that time believed to be the result of God's displeasure with humanity or the result of other supernatural powers or heavenly disturbances. Additionally, innocent groups of people were blamed for spreading the plague and were persecuted by the panicked masses. Numerous references in art, literature and public monuments attest to the horrors and devastation of that epidemic.

Centuries later, scientific inquiry determined that a bacterial disease spread by rat fleas was the cause of the plague that devastated Europe. Rat fleas became infected with bacteria while feeding on diseased rats. When rats were unavailable as a food source, the fleas sought other warm-blooded hosts, often humans, thereby vectoring the disease. Today this disease, known as bubonic plague, can be treated if properly diagnosed. Additionally, controlling rats and other rodents and fleas can reduce disease incidence.

Another historic pest infestation-one that directly influenced the population of the United States-was the destruction of Ireland's potato crop by a pest in the nineteenth century. A plant disease called late blight (Figure 1) essentially eliminated potatoes, the staple food crop in Ireland at that time. Up to a million Europeans starved to death during the Great Irish Famine of 1845 - 1847. Social implications of this pest infestation in Ireland included the largest ever migration to the United States, with more than a million people migrating to this country from Ireland during that famine.

Late blight continues to be a major pest of potatoes, but this plant disease is managed through the use of resistant potato cultivars, proper sanitation practices, and fungicides. Even today late blight is one of the major pathogens that chemical companies target in their search for new fungicides. The disease is caused by a fungus-like organism, Phytophthora infestans, which is a specialized pathogen of potato

1. This document is PI219, one of a series of the Agronomy Department, Florida Cooperative Extension Service, Institute of Food and Agricultural Sciences, University of Florida. Original publication date December 2009. Visit the EDIS Web Site at http://edis.ifas.ufl.edu.

2. Frederick M. Fishel, associate professor, Agronomy Department, and Director, Pesticide Information Office; Florida Cooperative Extension Service, Institute of Food and Agricultural Sciences, University of Florida, Gainesville, FL 32611.

The Institute of Food and Agricultural Sciences (IFAS) is an Equal Opportunity Institution authorized to provide research, educational information and other services only to individuals and institutions that function with non-discrimination with respect to race, creed, color, religion, age, disability, sex, sexual orientation, marital status, national origin, political opinions or affiliations. U.S. Department of Agriculture, Cooperative Extension Service, University of Florida, IFAS, Florida A. \& M. University Cooperative Extension Program, and Boards of County Commissioners Cooperating. Millie FerrerChancy, Interim Dean 
and, to a lesser extent, tomato, another member of the Solanaceous plant family.

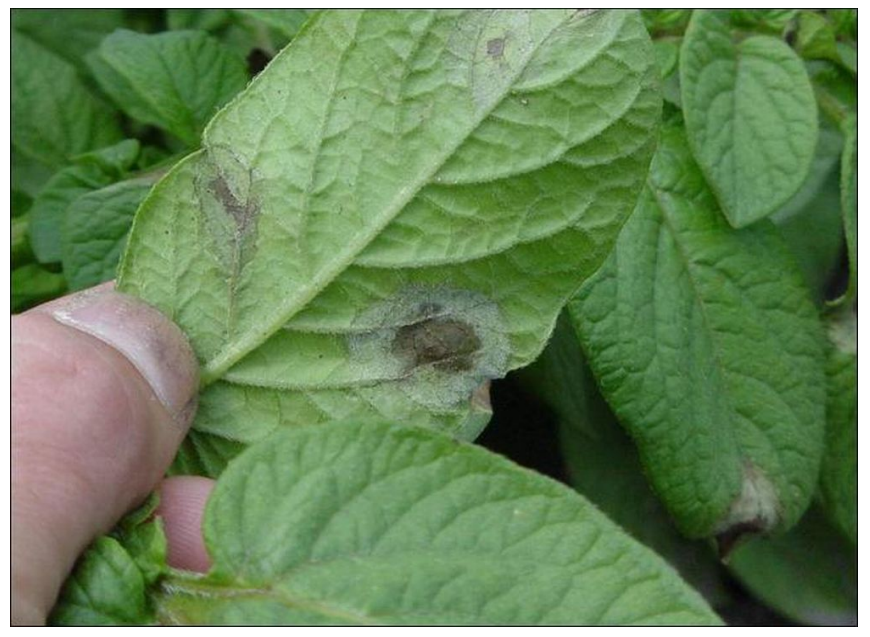

Figure 1. Potato late blight. Credit: UF/IFAS EDIS Doc. HS1010.

However, for many centuries_-including during the nineteenth century potato famine in Ireland, mystery surrounded the causes of crop failures, as well as human and animal diseases. The first pest-control measures were crude; weeds were pulled, rats were clubbed, and beetles were plucked from foliage.

\section{Early Uses of Pesticides and Fungicides}

Sulfur, also known as brimstone, was used by pagan priests 2,000 years before the birth of Christ. Pre-Roman civilizations burned brimstone as a medicine and used "bricks" of sulfur as fumigants, bleaching agents, and incense in religious rites. The Romans used sulfur - or fumes from its combustion-as an insecticide and to purify a sick room and cleanse its air of what was believed to be evil. The same uses of sulfur were reported by Homer in the Odyssey in 1000 B.C. Today, more than 50 sulfur products are registered for use as pesticides in Florida alone. Sulfur is used primarily for mite and disease control in a wide variety of crops and sites.

Through the years, experimentation and good fortune led to the recognition of additional chemicals with pesticidal activity. Early plant-derived insecticides included hellebore to control body lice, nicotine to control aphids, and pyrethrins to control a wide variety of insects. Lead arsenate was first used in 1892 as an orchard spray (Figure 2).

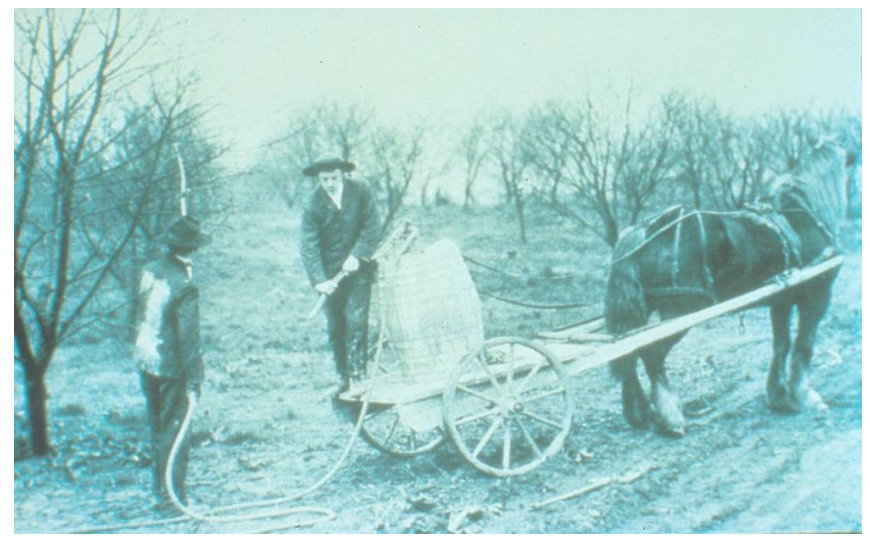

Figure 2. Orchard spraying circa 1900. Credit: UF/IFAS PIO.

The common plant disease, downy mildew, is partly responsible for the introduction of today's widely used fungicides. During the 1850 s in the Bordeaux Region of France, a vineyard producer was having problems with people pilfering grapes from his vines. Thinking that he could make the grapes unattractive to the thieves, he applied a mixture of copper and lime to part of his vineyards. The result not only deterred thieves, but it was also noticed that where the copper-lime mixture was applied, there was no disease incidence. This copper-lime mixture came to be known as Bordeaux mixture, a commonly used fungicide, even today. The discovery was the beginning of modern fungicide use.

\section{Other Insect Vectored Diseases Affecting Humans}

\section{Malaria}

Malaria is the most common and deadly parasitic disease in the world, transmitted by mosquitoes. Although malaria is an ancient disease, environmental disturbance, malnutrition and the failure of drugs once used to control the disease have conspired to make malaria as serious a problem now as it was during the first half of the twentieth century. In any given year, 6 - 9 percent of the global population (300 - 500 million cases annually) will suffer a case of malaria. Most who fall ill survive after an illness of 10 - 20 days, but $1-3$ percent of those who fall sick die as a result of this illness. Africa is terribly affected and accounts for more than 
90 percent of reported cases of malaria. For example, in Africa, a child dies from malaria every 30 seconds. Because malaria causes so much illness and death, the disease is a great drain on many national economies. Since many countries with malaria are already among the poorer nations, the disease maintains a vicious cycle of disease and poverty.

The Panama Canal is a major ship canal that traverses the Isthmus of Panama in Central America, connecting the Atlantic and Pacific Oceans. The construction of the canal was one of the largest and most difficult engineering projects ever undertaken. The project has had an enormous impact on shipping, as ships no longer have to travel the long and treacherous route via the Drake Passage and Cape Horn at the southernmost tip of South America. A ship sailing from New York to San Francisco via the canal travels 6,000 miles, well under half the distance of the distance of the route around Cape Horn-14,000 miles.

Although the idea of a canal in Panama dates back to the early sixteenth century, the first attempt to construct a canal in Panama began in 1880 under French leadership. After this attempt collapsed, the work was completed by the United States, and the canal opened in 1914. The building of the 48-mile canal was plagued by problems, including disease, particularly malaria and yellow fever-a major reason why the French abandoned the project.

As many as 27,500 workers are estimated to have died during construction of the canal. Following Dr. Walter Reed's discovery that yellow fever was transmitted by mosquitoes, the canal's completion was made possible through anti-mosquitoes measures. Since opening, the canal has been enormously successful and continues to be a key conduit for international shipping. Each year the canal accommodates the passage of more than 14,000 ships, carrying more than 203 million tons of cargo. By 2002 about 800,000 ships had passed through the canal.

\section{Typhoid Fever}

Flying insects feeding on feces may occasionally transfer the typhoid fever bacteria to food being prepared for consumption. This disease is most commonly transmitted through poor hygiene habits and inadequate public sanitation. Public education campaigns encouraging people to wash their hands after using the toilet and before handling food are an important component in controlling spread of typhoid fever.

A person may become an asymptomatic carrier of typhoid fever, suffering no symptoms, but capable of infecting others. According to the Centers for Disease Control, approximately 5 percent of people who contract typhoid continue to carry the disease after they recover. The most notorious carrier of typhoid fever, but by no means the most destructive, was Mary Mallon, also known as Typhoid Mary. In 1907 she became the first American carrier to be identified and traced. She was a cook in New York at the beginning of the twentieth century. Some believe she was the source of infection for several hundred people. She is closely associated with fifty cases and five deaths. Public health authorities told Mary to give up working as a cook or have her gall bladder removed. Mary quit her job, but returned later under a false name. She was detained and quarantined after another typhoid outbreak. She died of a stroke after 23 years in quarantine.

\section{Pest Control during WWII and in the Early Post-War Period}

Until the 1940s, pest-control chemicals were derived from plants and inorganic compounds. During World War II, DDT, a synthetic chemical, played an important role saving Allied soldiers from insect-transmitted diseases. DDT was hailed as the insecticide to solve all insect problems (Figure 3 and Figure 4). The introduction of countless other synthetic organic pesticides followed. These synthetic products launched the modern-day chemical industry and began a new era in pest control.

Given significant success at a relatively low cost, the use of pesticides became the primary means of pest control, providing season-long crop protection against pests and complementing the benefits of fertilizers and other agricultural production practices. The success of modern pesticides, particularly in agriculture and human health, encouraged widespread acceptance and eventual reliance on them. 


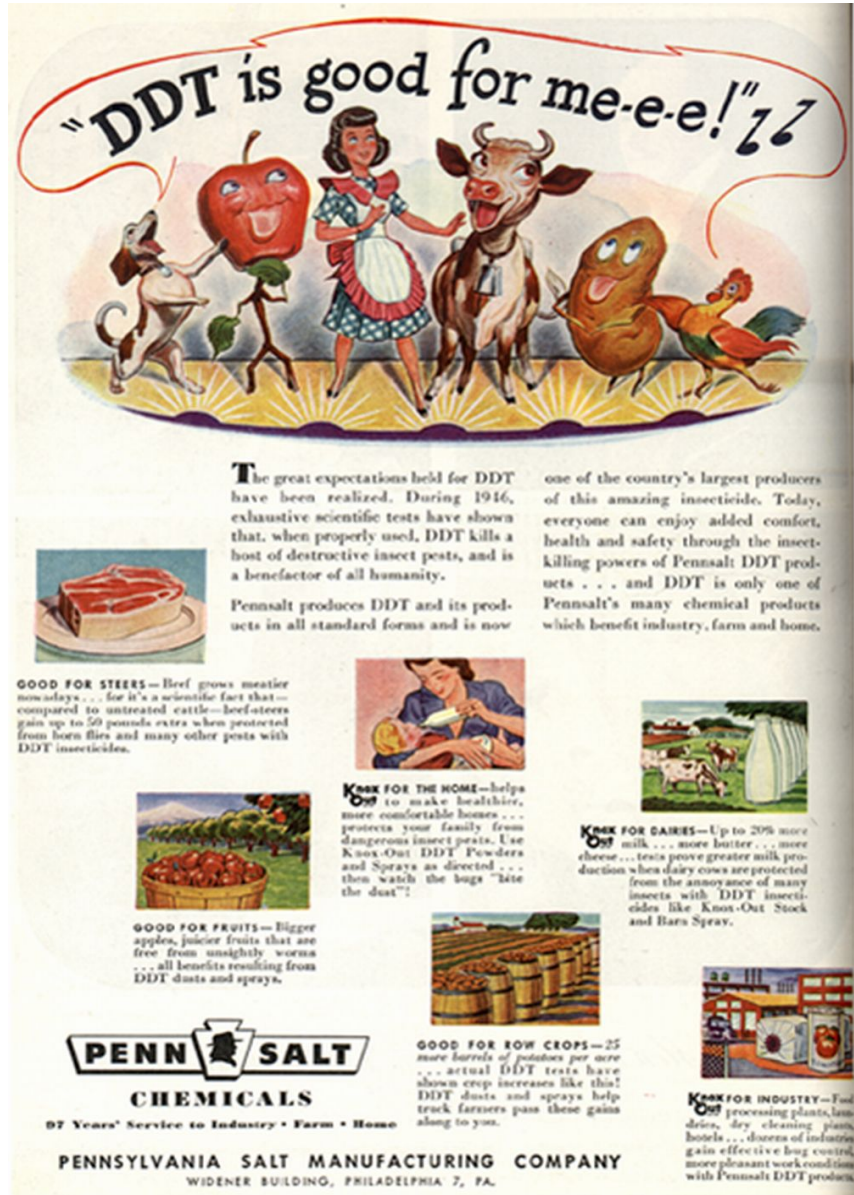

Figure 3. DDT advertisement flyer circa 1950. Credit: UF/IFAS PIO.

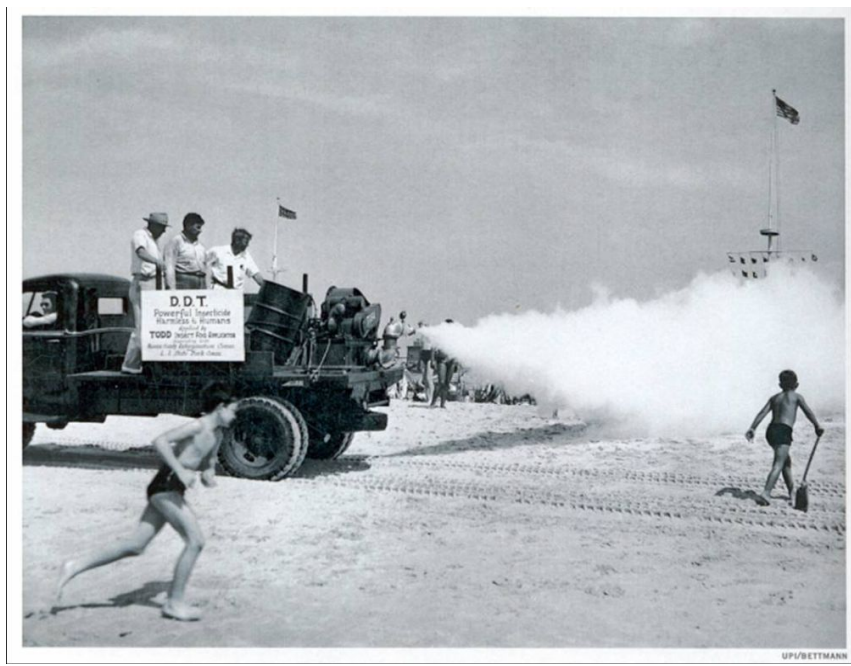

Figure 4. Area-wide DDT application circa 1950. Credit: UF/IFAS PIO.

\section{Contemporary Pest Control}

In recent years, some drawbacks of heavy dependence on pesticides have become increasingly apparent. One of the most disturbing is the development of pest resistance to pesticides. Since the resistance of the San Jose scale to lime sulfur was recognized in 1908, hundreds of insects have become resistant to one or more pesticides worldwide. It was ironic that within only a few years after the introduction of DDT, resistance was confirmed to the housefly in Sweden. Pesticide resistance also has arisen in more than 300 weed biotypes and many plant pathogens.

Growing concerns about the environmental and health hazards associated with pesticides have also become significant factors challenging pesticide use. In 1962, Dr. Rachel Carson published Silent Spring, a book that examined pesticides and their effects on the environment. DDT and other chlorinated hydrocarbons were her primary concern because of their stability and persistence in the environment. The long residual activity of these substances was a major factor contributing to their effectiveness, but a negative effect was their ability to accumulate in the fatty tissue of some animals, a process known as bioaccumulation. In certain situations, biomagnification of the insecticides occurred whereby some organisms accumulate chemical residues in higher concentrations than those found in the organisms they consume (Figure 5).

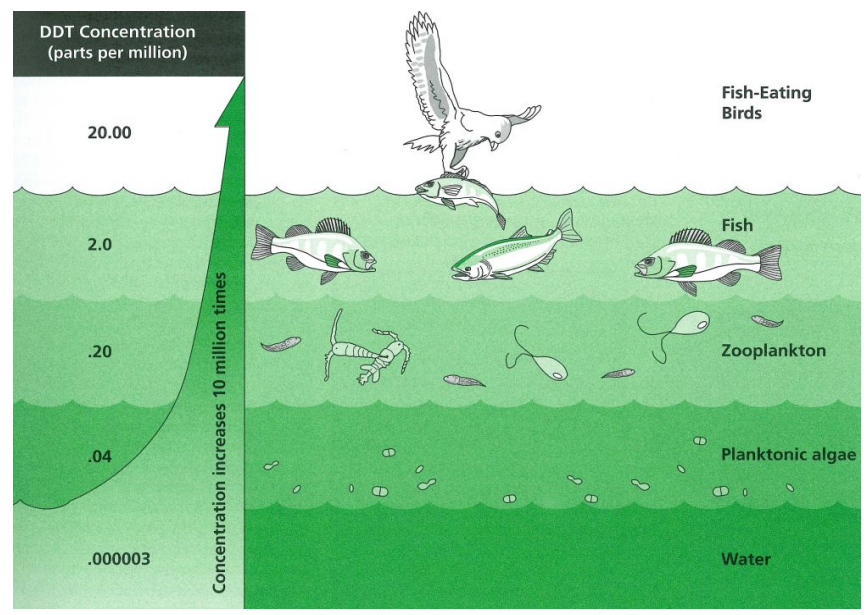

Figure 5. Schematic depiction of biomagnification. Credit: Adapted from National Pesticide Applicator Certification Core Manual.

Since the publication of Silent Spring, the United States has experienced a level of unprecedented environmental awareness. The U.S. Environmental Protection Agency (EPA) was created in 1970 with a mandate from Congress. The EPA's task was then, 
and remains today, to implement by regulation the laws passed by Congress to protect the environment and the health of humans and other animals. Since the 1972 EPA ban on DDT use in the United States, regulatory action has been taken against many chemicals, including pesticides, thought to pose significant environmental and health hazards. Public concern has led to stringent regulation of pesticides and changes in the types of pesticides used (Figure 6).

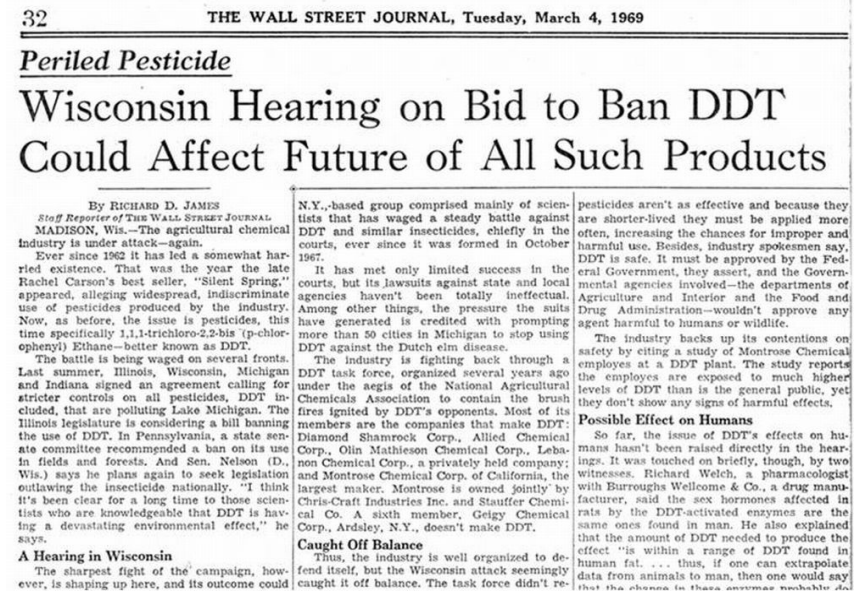

Figure 6. Press release regarding DDT ban. Credit: UF/IFAS PIO.

\section{A Chronological List of Selected Significant Events Involving Pesticides}

- 12000 BC: First records of insects in human society.

- 2000 BC: First reported use of sulfur as a pesticide by pre-Roman civilizations.

- 1200 BC: First reports of nonselective herbicide use as biblical armies salt and ash the fields of the conquered.

- 100 BC: The Romans apply hellebore for control of rats, mice, and insects.

- 300: Earliest recording of biological control Chinese use predatory ants in citrus for control of destructive insects.

- 900: Chinese use arsenic to control garden insects.
- 1649: Rotenone used to paralyze fish in South America.

- 1690: Nicotine extracted from tobacco for insecticide use.

-1787: Soap mentioned as an insecticide.

- 1848: Rotenone used as an insecticide in Asia.

- 1850's: Lime and copper mixture used for plant disease control on grape in France.

- 1860's: Paris green, an arsenical, used as an insecticide for control of Colorado potato beetle.

-1873: DDT first made in the laboratory.

-1882: Bordeaux mixture discovered in France for control of plant diseases.

-1883: John Bean invents pressure sprayer for pesticide application leading to efficient applications to crops.

-1886: Hydrogen cyanide fumigant use in California citrus.

- 1892: Lead arsenate discovered for gypsy moth control in Massachusetts.

- 1894 - 1900: Steam-, mechanical-, and horse-driven pesticide spray equipment developed.

- 1907 - 1911: Industry begins production of lead arsenate.

- 1910: Passage of Federal Insecticide Act (precursor to today's Federal Insecticide, Fungicide, and Rodenticide Act).

-1921: First use of airplane to apply a pesticide.

-1927: Tolerance established for arsenic on apples by U.S. Food and Drug Administration.

- 1932: Methyl bromide first used as a fumigant in France. 
- 1932 - 1939: Insecticidal properties of DDT studied and described in Switzerland.

-1936: Pentachlorophenol introduced as a wood preservative.

-1942: DDT made available for U.S. military use (civilian use available in 1945).

- 1942: Phexoxy acetic acids', including, 2,4-D, herbicidal properties described.

-1944: Introduction of warfarin for rodent control

- 1946: Organophosphates insecticides, developed in Germany, made available in United States.

-1950's - 1960's: Massive industrial research, development, and commercialization of multiple classes and families of pesticides.

- 1961: Bacillus thuringiensis first registered.

-1962: Publication of Silent Spring by Dr. Rachel Carson.

- 1965: Atrazine registered as a herbicide.

- 1970: Formation of the U.S. Environmental Protection Agency (responsible for pesticide registration).

-1971: Herbicidal properties of glyphosate described.

- 1973: Development of first photo-stable synthetic pyrethroid insecticide, permethrin.

-1973: DDT uses cancelled by the EPA.

- 1978: EPA releases first list of restricted use pesticides.

-1980's: EPA cancels many uses of chlorinated hydrocarbon pesticides.

- 1996: Monsanto introduces Roundup Ready® soybeans, the first transgenic crop with major market prospects.
- 1996: Food Quality Protection Act becomes law.

- 1990s and 2000s: Mergers and buyouts in the pesticide industry.

\section{References}

Ennis, W. B., Jr., and McClellan, W. D.

Chemicals in Crop Production, in Yearbook of Agriculture, 1964, USDA, Washington, D.C., 1964.

Jones, D. Price. Agricultural Entomology, in History of Entomology, Edited by Ray F. Smith, et. al., Annual Reviews, Palo Alto, CA, 1973.

Mrak, Emil. Pesticides and Their Relationship to Environmental Health, U.S. Dept of HEW, Washington, D.C., 1969.

Ordish, George. The Constant Pest; A Short History of Pests and Their Control, Charles Scribners Sons, New York, 1976.

Perkins, John H. The Introduction of DDT to the United States; Reshaping Insect Control Technologies in Wartime. Miami Univ., Oxford, Ohio, undated, circa 1975

Shepard, Harold H. The Chemistry and Action of Insecticides, 1st edition, McGraw-Hill, New York, 1951.

Ware, G.W. and D.M. Whitacre. History of Pesticides, in The Pesticide Book, 6th edition, MeisterPro Information Resources, Willoughby, $\mathrm{OH}$, 2004. 